\author{
Janusz Niczyporuk \\ Maria Curie-Skłodowska University in Lublin, Poland \\ ORCID: 0000-0003-1632-1784 \\ janusz.niczyporuk@umcs.pl
}

\title{
Evolution of Forms of Deciding an Administrative Case
}

\author{
Ewolucja form załatwienia sprawy administracyjnej
}

\begin{abstract}
The issue of the forms of deciding an administrative case has not yet been analysed in a comprehensive manner. First of all, attention used to be paid to individual forms of deciding on an administrative case, namely: administrative decision, administrative ruling, administrative settlement and deciding an administrative case in a tacit manner. If there were collective generalizations made, they came down to administrative decision and administrative ruling, which are classified as classic administrative acts, while the recent introduction of non-typical forms of deciding an administrative case, i.e. administrative settlement and deciding an administrative case in a tacit manner, makes us re-consider the characteristics of their catalogue; in particular, it should be noted at this point that they constitute a substitute for an administrative decision, which is considered to be a classic administrative act. The evolution of the forms of deciding on an administrative case leads to the conclusion that their relationship with the administrative jurisdiction has ceased to be so obvious.
\end{abstract}

Keywords: administrative decision; administrative jurisdiction; deciding an administrative case in a tacit manner; administrative ruling; administrative settlement; deciding on an administrative case

\section{INTRODUCTION}

The primary aim of the administrative procedure is still the deciding on a particular administrative case, despite many statutory changes that have taken place over the last few years, which were reflected primarily in the scope of application

CORRESPONDENCE ADDRESS: Janusz Niczyporuk, Prof. Dr. Habil., Full Professor, Head of Department of Administrative Proceedings, Maria Curie-Skłodowska University (Lublin), Faculty of Law and Administration, Institute of Law, Plac Marii Curie-Skłodowskiej 5, 20-031 Lublin, Poland. 
of the Polish Code of Administrative Procedure. ${ }^{1}$ The Code of Administrative Procedure is generally recognized as the basic legal act regulating administrative procedure. As a result, this procedure comprises also jurisdictional administrative proceedings, as we must always take into account the provision of Article 1 (1) and (2) CAP. Jurisdictional administrative procedure is involved when it comes the consequences of the norms of substantive administrative law are established in a binding manner using the norms of procedural administrative law, of course provided that they were included in the Code of Administrative Procedure. ${ }^{2}$ Thus, the administrative case is decided by settling the legal consequences. The substantive norm must therefore be specified, which will result in the release of its binding force. ${ }^{3}$ With such an assumption, jurisdictional administrative proceedings should be equated with general proceedings, because only the provisions of the Code of Administrative Procedure will be applicable to it. ${ }^{4}$ By analogy, the jurisdictional administrative proceedings can also be referred to a separate (special) procedure, in which the provisions of the Code of Administrative Procedure are only partially applicable. ${ }^{5}$ On the other hand, it is not possible to look for links with the separated proceedings, in which - as a rule - the provisions of the Code of Administrative Procedure governing jurisdictional proceedings do not apply. ${ }^{6}$

\section{TERMINOLOGY OF FORMS OF DECIDING AN ADMINISTRATIVE CASE}

From the perspective of the forms of deciding an administrative case, we need to start with terminological considerations. Therefore, it should now be stressed that the term "deciding a case" is a legal term (Article 1 (2) and Articles 35 to 38 CAP). Although it does not have a statutory definition, it can be clearly stated that the concept of deciding a case should now be defined as resolving it by way of an administrative decision or resolving it in a tacit manner (Article 1 (1) in fine CAP). At the same time, it is worth adding that the term "deciding a case" is a complex term, because it also contains the term "case" which occurs independently (Articles 35 to 38 CAP). Undoubtedly, the term "case" is of a legal nature and it may also

1 Act of 14 June 1960 - Code of Administrative Procedure (Journal of Laws 2021, item 735, as amended), hereinafter: CAP.

2 See M. Zimmermann, Z rozważań nad postępowaniem jurysdykcyjnym i pojęciem strony w Kodeksie postępowania administracyjnego, [in:] Księga pamiatkowa ku czci Kamila Stefki, Warszawa-Wrocław 1967, p. 433 ff.

3 See T. Kiełkowski, Sprawa administracyjna, Kraków 2004, p. 32.

4 See T. Woś, Kategorie postępowań jurysdykcyjnych, [in:] Postępowanie administracyjne, ed.

T. Woś, Warszawa 2017, p. 97.

5 Ibidem.

6 Ibidem. 
be equated with the legal term "individual case" (Article 1 (1) CAP). Unfortunately, the term "individual case" does not have its statutory definition, so it must be further defined in legal terms, which is traditionally done within the term "administrative case". By way of example, the traditional view that an administrative case is a possibility, provided for in the norms of substantive administrative law, of a concretisation in the factual states specified in those norms the mutual rights and obligations of the parties to the administrative and legal relationship, namely the administrative body and the individual entity not subordinated organizationally to this body. ${ }^{7}$ In this context, the term "form" is a legal term which reflects a distinctive, legally defined, well-established type of legal fact. ${ }^{8}$

The forms of deciding administrative cases have evolved considerably over the last almost hundred years. Since the legislature, when referring to the forms of deciding an administrative case, first used the concept of "decision" in the large sense, distinguishing between main decisions and incidental decisions (Article 72 (2) of the Regulation of the President of the Republic of Poland of 22 March 1928 on administrative procedure ${ }^{9}$ ), the main administrative case covered by administrative proceeding dealt with its merits or concluded at all the administrative case at the instance concerned. However, the incidental decision was intended to adjudicate on other matters arising during the administrative procedure. Subsequently, the legislature, already as part of the administrative procedure code regulation, maintained the substantive convention of the existing regulation, although it adopted a slightly changed conceptual framework, as it distinguished decision in the strict sense (Pol. decyzja) (Article $97 \mathrm{CAP}$ in the original form) and ruling (Pol. postanowienie) (Article $106 \mathrm{CAP}$ in the original form). ${ }^{10}$ Therefore, the decision in the strict sense was used to resolve the administrative case, as it decided on the merits of the administrative case in whole or in part, or otherwise concluded the administrative case at a given instance. By contrast, the resolution could not then conclude the administrative case, as it concerned individual questions arising in the course of the proceedings, but did not decide on the merits of the administrative case.

7 See idem, Ogólne postępowanie administracyjne jurysdykcyjne. Uwagi wprowadzające, [in:] Postępowanie administracyjne..., p. 122.

8 Cf. K.M. Ziemski, Indywidualny akt administracyjny jako forma prawna działania administracji, Poznań 2005, p. 138.

9 Journal of Laws 1928, no. 36, item 341, as amended; now non-applicable.

${ }^{10}$ M. Dyl, Postanowienia, [in:] Postępowanie administracyjne i sadowoadministracyjne, ed. M. Wierzbowski, Warszawa 2020, p. 241. 


\section{CATALOGUE OF FORMS OF DECIDING AN ADMINISTRATIVE CASE}

Ultimately, therefore, an administrative decision and an administrative ruling were distinguished, but eventually these terms were given a slightly different meaning. Thus, an administrative decision still resolves an administrative case unless the provisions of the Code of Administrative Procedure provide otherwise, because it resolves an administrative case on its merits in whole or in part, or otherwise concludes an administrative case at a given instance (Article 104 CAP). On the other hand, an administrative ruling may resolve an administrative case in an exceptional way, since it concerns particular issues arising in the course of administrative proceedings, at the same time not deciding on the merits of an administrative case, unless the provisions of the Code of Administrative Procedure provide otherwise (Article 123 CAP). Recently, when another amendment was made to the Code of Administrative Procedure, administrative settlement appeared as an alternative to administrative decision and a non-sovereign way of resolving administrative cases (Article 114 CAP). ${ }^{11}$ Undoubtedly, administrative settlement is an acceptable way of amicable resolution of an administrative case, which implements the principle of settling contentious matters in an amicable way (Article 13 CAP). ${ }^{12}$ Quite recently, on the occasion of another amendment of the Code of Administrative Procedure, the resolving of an administrative case in a tacit manner was introduced (Article 122a $\S 1$ CAP). ${ }^{13}$ Nowadays, an administrative case is not only resolved by way of an administrative decision, but it may sometimes be "resolved tacitly" if a specific provision so provides. ${ }^{14}$

It is definitely necessary to establish the meaning of the two concepts mentioned at the end, the designata of which are not sufficiently defined in law. The concept of an administrative settlement most often boils down to mutual concessions made by the parties to administrative proceedings with regard to their rights and obligations. ${ }^{15}$ Therefore, the concept of administrative settlement should be understood as an agreement between the parties, concluded before an administrative body and governing their mutual rights and obligations in an individual case covered

${ }^{11}$ See M. Strożek-Kucharska, K. Grochol, Ugoda administracyjna w świetle nowelizacji Kodeksu postępowania administracyjnego z 2017 r., [in:] Nowe instytucje procesowe $w$ postepowaniu administracyjnym $w$ świetle nowelizacji Kodeksu postępowania administracyjnego z dnia 2 kwietnia 2017 r., eds. A. Gronkiewicz, A. Ziółkowska, Katowice 2017, p. 76; Article 11 (55) of the Act of 31 January 1980 on the Supreme Administrative Court and on amendment of the Code of Administrative Procedure (Journal of Laws 1980, no. 4, item 8, as amended).

${ }_{12}$ See M. Grzywacz, Ugoda administracyjna, [in:] Postępowanie administracyjne..., p. 223.

13 See Act of 7 April 2017 on amendment of the Code of Administrative Procedure and certain other acts (Journal of Laws 2017, item 935).

${ }^{14}$ See M. Kamiński, Milczace załatwienie sprawy, [in:] Postępowanie administracyjne..., p. 446.

${ }^{15}$ See H. Knysiak-Sudyka, Ugoda administracyjna, [in:] Postępowanie administracyjne..., p. 432. 
by administrative proceedings. ${ }^{16}$ In other words, the concept of administrative settlement can be understood as an agreement between the parties concluded during administrative proceedings, regulating their mutual rights and obligations in an individual case that is subject to administrative proceedings, and approved by the administrative body of charge of the proceedings. ${ }^{17}$ On the other hand, the concept of deciding an administrative case in a tacit manner has not yet found a well-established definition..$^{18}$ Obviously this definition must be built around the idea of an implicit administrative act, or more precisely the construction of the legal fiction of resolution ${ }^{19}$ since it assumes the introduction of the fiction of positive resolving of an administrative case, i.e. accepting the demand of a party to administrative proceedings in a situation where the administrative body fails to respond to the actions of a party to administrative proceedings within a specified period. ${ }^{20}$

\section{FORMS OF DECIDING AN ADMINISTRATIVE CASE AS AN ADMINISTRATIVE RESOLUTION}

Such forms of deciding an administrative case in administrative proceedings must then be identified as determining (decisive) actions, since they have the attribute of an administrative resolution. ${ }^{21}$ The division of resolutions issued by the administrative body during administrative proceedings was first based on the classic assumption that administrative decision, as an act of application of provisions of substantive administrative law, resolves the administrative case on the merits by shaping the legal position of a party to the administrative procedure in terms of rules of substantive administrative law, whereas administrative ruling, as an act of application of rules of procedural administrative law, does not determine the substantive-law situation of a party to administrative proceedings, but only decides on the procedural issues that arise during the administrative proceedings. ${ }^{22}$ Although

${ }^{16}$ See W. Chróścielewski, Akty kończące postępowanie, [in:] W. Chróścielewski, J.P. Tarno, Postępowanie administracyjne i postępowanie przed sadami administracyjnymi, Warszawa 2004, p. 160.

17 See J. Wyporska-Frankiewicz, Publicznoprawne formy dziatania administracji o charakterze dwustronnym, Warszawa 2010, p. 106.

18 See J. Wegner, Instytucja milczacego załatwienia sprawy przez administracje publiczna, Warszawa 2021, p. $85 \mathrm{ff}$.

19 Ibidem, p. 23 ff.

${ }^{20}$ See T. Majer, Milczace zalatwienie sprawy administracyjnej, [in:] Podstawowe instytucje postępowania administracyjnego, eds. P. Krzykowski, A. Skóra, T. Majer, Olsztyn 2020, p. 192.

${ }^{21}$ See G. Łaszczyca, Postanowienie administracyjne w ogólnym postępowaniu administracyjnym, Warszawa 2011, p. 31.

${ }^{22}$ See M. Bogusz, Postanowienie materialnoprawne, [in:] Leksykon prawa administracyjnego materialnego. 100 podstawowych pojęć, eds. T. Bąkowski, K. Żukowski, Warszawa 2016, pp. 153-154. 
legal provisions modify this assumption on several occasions, allowing, on the one hand, the possibility of adopting an administrative decision which is merely an act of application of administrative procedural law (decision to discontinue administrative proceedings) and, on the other, the possibility of issuing an administrative ruling which has an effect on the substantive-law situation of a party to administrative proceedings. ${ }^{23}$

Today, however, it is difficult to speak of preserving the classic division of resolutions made by an administrative body in administrative proceedings, since new forms of deciding an administrative case must also be taken into account. Of course, administrative settlement is then a substitute for a classic administrative resolution, ${ }^{24}$ as it means resignation from a sovereign and unilateral resolving of an administrative case in favour of a resolution that is a result of mutual concessions of the parties to administrative proceedings. ${ }^{25}$ Nevertheless, administrative settlement is considered to be a legal form of administrative action, whose character was developed to such an extent that the Code of Administrative Procedure can present it as a separate form of deciding an administrative case. ${ }^{26}$ Similarly, deciding an administrative case in a tacit way is only a substitute for a classic administrative decision, ${ }^{27}$ as the tacit resolution of an administrative case takes the form of a decision on the merits of the administrative case, in accordance with the content and scope of the demand of a party to the administrative proceedings, which as a result of inactivity of the administrative body is, by virtue of legal fiction (Article 122a $\S 2$ in principio CAP), is deemed to have been accepted in its entirety. ${ }^{28}$ Therefore it may be treated as a legal form of administrative action, by means of which this body tacitly expresses its will. ${ }^{29}$ Administrative silence thus constitutes a separate form of settling an administrative matter, which is not based on an action of the administrative body.

\section{GROUPS OF FORMS OF DECIDING AN ADMINISTRATIVE CASE}

Consequently, it must now be concluded that the forms of deciding an administrative case are not uniform. On the one hand, it is necessary to distinguish classical forms, namely administrative decision and administrative ruling, while on

${ }^{23}$ Ibidem, p. 154.

${ }^{24}$ See W. Wierzbowski, Istota i rozwój postępowania administracyjnego, [in:] Postęowanie administracyjne..., p. 2.

${ }^{25}$ See J. Wyporska-Frankiewicz, op. cit., pp. 77-78.

${ }^{26}$ Ibidem, p. 75.

${ }^{27}$ See M. Kamiński, op. cit., p. 447.

${ }^{28}$ Ibidem.

29 See J. Zimmermann, Prawo administracyjne, Warszawa 2016, p. 449. 
the other hand, it is necessary to supplement them now with non-classical forms, namely administrative settlements and deciding an administrative case in a tacit manner. The classic forms of deciding an administrative case cannot, however, be opposed to the non-classical forms of deciding an administrative case, since functional links are apparent between them since administrative settlement must be approved by the administrative body before which it was concluded in the form of an administrative ruling, which is a condition for its legal effect (Article $18 \S 1$ CAP).$^{30}$ An approved administrative settlement has the same legal effects as an administrative decision adopted in the course of administrative proceedings in accordance with Article $121 \mathrm{CAP}$. The tacit deciding of an administrative case occurs only when the administration body fails to decide the administrative case by way of an administrative decision within the statutory period. An external confirmation of the tacit deciding of an administrative case is a certificate issued in the form of an administrative ruling (Article $122 \mathrm{f} \S 1 \mathrm{CAP}$ ). ${ }^{31}$

The forms of deciding an administrative case should therefore be included in the two groups referred to above, using the criterion of how an administrative resolution may be appealed against. If, therefore, they have the inherent value of an administrative resolution, then they are classical forms of deciding an administrative case. This point of view then makes it possible to highlight the sovereign nature of classical forms of deciding administrative cases, because they are characterized by the unilateralism of the decision taken and an indirect decision-making. The administrative body makes use of the administrative authority when it decides on the rights or obligations of a party to administrative proceedings by extracting them from a rule of substantive administrative law in a given factual situation. ${ }^{32}$ When the inherent value of the administrative resolution cannot be found, these are non-classical forms of deciding an administrative case. At the same time, such a point of view calls into question the sovereign nature of non-classical forms of deciding an administrative case, since they are not characterised, as a rule, by the unilateralism of the resolution and by indirect decision-making. An administrative body may use its administrative powers narrowly when it approves an administrative settlement or waives its powers in the tacit resolution of an administrative case.

\footnotetext{
${ }^{30}$ See H. Knysiak-Sudyka, op. cit., p. 438.

31 See A. Gronkiewicz, Milczace załatwienie sprawy jako nowa instytucja postepowania administracyjnego, [in:] Nowe instytucje procesowe..., p. 236.

32 See J. Zimmermann, Polska jurysdykcja administracyjna, Warszawa 1996, p. 129.
} 


\section{CONCLUSIONS}

It must be stated that the forms of deciding an administrative case have evolved, as two new forms developed, which do not have a traditionally understood link with administrative jurisdiction. The deciding of an administrative case by means of an administrative decision or administrative ruling alone no longer meets the needs of modern administrative legal transactions. Above all, it is about democratisation and streamlining, for which administrative settlement and deciding a case in a tacit manner fit particularly well. But it must be fairly acknowledged that the introduction of administrative settlement and the tacit deciding of an administrative case raise controversy in many aspects. From a systemic perspective, it is considered that they challenge the established nature of forms of deciding an administrative case, as they are not, in principle, of a sovereign nature. In addition to the systemic perspective, however, their practical significance is questioned, but not for their legal structure. This is especially noticeable for administrative settlement, with few cases of actual application so far, although there are enormous possibilities in it. ${ }^{33}$ When it comes to the tacit deciding of an administrative case, it has been an object of undeserved criticism, as it is referred to by few acts of substantive administrative law.

\section{REFERENCES}

\section{Literature}

Bogusz M., Postanowienie materialnoprawne, [in:] Leksykon prawa administracyjnego materialnego. 100 podstawowych pojęć, eds. T. Bąkowski, K. Żukowski, Warszawa 2016.

Chróścielewski W., Akty kończace postępowanie, [in:] W. Chróścielewski, J.P. Tarno, Postępowanie administracyjne i postepowanie przed sadami administracyjnymi, Warszawa 2004.

Dyl M., Postanowienia, [in:] Postępowanie administracyjne i sądowoadministracyjne, ed. M. Wierzbowski, Warszawa 2020.

Gronkiewicz A., Milczace załatwienie sprawy jako nowa instytucja postępowania administracyjnego, [in:] Nowe instytucje procesowe $w$ postępowaniu administracyjnym $w$ świetle nowelizacji Kodeksu postępowania administracyjnego z dnia 2 kwietnia 2017 r., eds. A. Gronkiewicz, A, Ziółkowska, Katowice 2017.

Grzywacz M., Ugoda administracyjna, [in:] Postepowanie administracyjne i sądowoadministracyjne, ed. M. Wierzbowski, Warszawa 2020.

Kamiński M., Milczące załatwienie sprawy, [in:] Postępowanie administracyjne, ed. T. Woś, Warszawa 2017.

Kiełkowski T., Sprawa administracyjna, Kraków 2004.

Knysiak-Sudyka H., Ugoda administracyjna, [in:] Postępowanie administracyjne, ed. T. Woś, Warszawa 2017.

${ }^{33}$ See M. Strożek-Kucharska, K. Grochol, op. cit., p. 77. 
Łaszczyca G., Postanowienie administracyjne w ogólnym postępowaniu administracyjnym, Warszawa 2011.

Majer T., Milczace załatwienie sprawy administracyjnej, [in:] Podstawowe instytucje postępowania administracyjnego, eds. P. Krzykowski, A. Skóra, T. Majer, Olsztyn 2020.

Strożek-Kucharska M., Grochol K., Ugoda administracyjna w świetle nowelizacji Kodeksu postępowania administracyjnego z 2017 r., [in:] Nowe instytucje procesowe w postępowaniu administracyjnym w świetle nowelizacji Kodeksu postępowania administracyjnego z dnia 2 kwietnia 2017 r., eds. A. Gronkiewicz, A. Ziółkowska, Katowice 2017.

Wegner J., Instytucja milczacego załatwienia sprawy przez administracje publiczna, Warszawa 2021. Wierzbowski W., Istota i rozwój postęopowania administracyjnego, [in:] Postępowanie administracyjne i sadowoadministracyjne, ed. M. Wierzbowski, Warszawa 2020.

Woś T., Kategorie postępowań jurysdykcyjnych, [in:] Postępowanie administracyjne, ed. T. Woś, Warszawa 2017.

Woś T., Ogólne postępowanie administracyjne jurysdykcyjne. Uwagi wprowadzające, [in:] Postępowanie administracyjne, ed. T. Woś, Warszawa 2017.

Wyporska-Frankiewicz J., Publicznoprawne formy działania administracji o charakterze dwustronnym, Warszawa 2010.

Ziemski K.M., Indywidualny akt administracyjny jako forma prawna działania administracji, Poznań 2005.

Zimmermann J., Polska jurysdykcja administracyjna, Warszawa 1996.

Zimmermann J., Prawo administracyjne, Warszawa 2016.

Zimmermann M., Z rozważań nad postępowaniem jurysdykcyjnym i pojęciem strony w Kodeksie postępowania administracyjnego, [in:] Księga pamiątkowa ku czci Kamila Stefki, WarszawaWrocław 1967.

\section{Legal acts}

Act of 14 June 1960 - Code of Administrative Procedure (Journal of Laws 2021, item 735, as amended).

Act of 31 January 1980 on the Supreme Administrative Court and on amendment of the Code of Administrative Procedure (Journal of Laws 1980, no. 4, item 8, as amended).

Act of 7 April 2017 on amendment of the Code of Administrative Procedure and certain other acts (Journal of Laws 2017, item 935).

Regulation of the President of the Republic of Poland of 22 March 1928 on administrative procedure (Journal of Laws 1928, no. 36, item 341, as amended).

\section{ABSTRAKT}

Zagadnienie form załatwienia sprawy administracyjnej nie było dotąd analizowane w sposób kompleksowy. Przede wszystkim bowiem zwracano uwagę na poszczególne formy załatwienia sprawy administracyjnej, a mianowicie: decyzję administracyjną, postanowienie administracyjne, ugodę administracyjną i milczące załatwienie sprawy administracyjnej. Jeżeli dochodziło już do zbiorczych uogólnień, to ograniczały się one do decyzji administracyjnej i postanowienia administracyjnego, które zalicza się do klasycznych aktów administracyjnych. Tymczasem wprowadzenie ostatnio nietypowych form załatwienia sprawy administracyjnej, czyli ugody administracyjnej i milczącego załatwienia sprawy administracyjnej, zmusza do ponownej refleksji teoretycznej nad charakterystyką wyróżnionego ich katalogu. W szczególności należy podkreślić, że stanowią one substytut 
Pobrane z czasopisma Studia Iuridica Lublinensia http://studiaiuridica.umes.pl Data: 26/04/2023 07:14:27

rozstrzygnięcia administracyjnego, za jaki uznaje się klasyczny akt administracyjny. Ewolucja form załatwienia sprawy administracyjnej prowadzi zatem do wniosku, że ich związek z jurysdykcją administracyjną przestaje być oczywisty.

Słowa kluczowe: decyzja administracyjna; jurysdykcja administracyjna; milczące załatwienie sprawy administracyjnej; postanowienie administracyjne; ugoda administracyjna; załatwienie sprawy administracyjnej 